\title{
Evaluation of a new probiotic concept for broilers
}

2

3

4

5

6

7

8

9

10

11 Running title: New probiotic concept

12

13 Key words: Poultry, Lactobacillus agilis, Enterococcus faecalis, Escherichia coli

14

15

16

\section{S. L. Jørgensen, ${ }^{1, a}$ L. L. Poulsen, ${ }^{1, a}$ M. Bisgaard, ${ }^{2}$ and H. Christensen ${ }^{1 *}$}

${ }^{1}$ University of Copenhagen, Department of Veterinary and Animal Sciences, Frederiksberg, Denmark;

${ }^{2}$ Bisgaard Consulting, Viby Sjælland, Denmark;

a Authors contributed equally;

*Corresponding author: Email hech@sund.ku.dk 


\section{SUMMARY}

Probiotics were introduced as a spray directly in the hatcher when chickens started to leave the eggs which potentially could reduce the horizontal transmission and colonization with pathogenic bacteria. The single introduction of probiotics could limit the cost compared to multiple introductions with feed and/or water. A mixture of five probiotic strains belonging to Escherichia coli, Enterococcus faecalis, Lactobacillus agilis and Lactobacillus rhamnosus was tested with two independent flocks of broilers (Ross 308). For each experiment, a comparison was made to an untreated control flock on the same farm. At day 14 of production the probiotic strains were re-isolated from ileum of euthanized chickens. The first week mortality was slightly increased in the probiotic flock $(0.42 \%)$ compared to the control $(0.35 \%)$ in experiment 1 , however, it was higher in the control flock $(1.45 \%)$ compared to the probiotic flock $(1.12 \%)$ in experiment 2. The average weight of chickens that could be slaughtered for consumption was increased by $3.5 \%$ in the probiotic flocks compared to the control flocks, resulting in a $1.9 \%$ higher total weight of slaughtered chickens in the probiotics treated flocks compared to the control as a mean of the two experiments. The number of condemned animals was within the normal range for the production system and could not directly be related to effects of probiotics. Although one probiotic strain of $E$. coli was isolated from dead animals, the probiotics did not affect the proportion of chickens which died due to E. coli during the first week compared to the control.

\section{DESCRIPTION OF PROBLEM}

Bacterial infections in industrialized chickens can cause high mortality and major economic costs [1,2]. Bacteria including Escherichia coli, enterococci and staphylococci have been reported most frequently to contribute to bacterial disease in poultry, being associated with septicemia, omphalitis, salpingitis and endocarditis [3, 4, 5]. Vertical transmission from the parent hen to the chicks and subsequent horizontal transmission in the hatcher has been considered to be the main route of the infectious agent to spread $[5,6]$.

The chicken's first week of live has been found critical and the main bacterial challenge has been E. coli [7]. Producers aim to keep first week mortality (FWM) below 0.7\% [8]. Antibiotics have traditionally been preferred to control FWM. However, due to the 
47 development of antibiotic-resistant bacteria, alternative treatment methods have been proposed to 48 reduce bacterial infections.

50 found on the eggshells in the hatchers and bacteria of chicks which may hatch with a vertical

51 transmitted infection [5]. The colonization route of chickens provided the idea to use a new way

52 to deliver probiotics to the chickens. A novel application method (new probiotic concept, NPC)

53 has been introduced applying the probiotic bacteria in the hatchers during the hatching proces.

54 The probiotics were sprayed in the hatcher at the time point where $50 \%$ of the eggs had hatched.

55 The method relied on the further horizontal transmission of the probiotic strains and colonization

56 of the hatching chicks.

Probiotics have been defined as "a live microorganisms which, when administrated in adequate amounts, confer a health benefit on the host" [9]. Probiotics have been used as prophylactic treatment of industrialized chickens and a wide range of bacterial strains and application methods have been described [10-12]. Several bacterial species have been investigated for a probiotic protential. Most significantly lactobacilli have been shown to have a protective effect against pathogenic bacteria as well as a beneficial effect on the digestive and immune responses in chickens. Additionally, both Enterococcus faecium and Escherichia coli have been shown to have a similar positive effect in chickens under experimental conditions [1365 19]. probiotics in particular have have been demonstrated to have positive effects in the control of pathogenic bacteria, including species of Campylobacter, Salmonella as well as E. coli [11, 20,

69 21]. Unfortunately most studies performed and positive results reported have been obtained under experimental conditions and not on farm level. setting and to test the effect of the NPC on hatchability, FWM, feed conversion ratio (FCR), production efficiency factor (PEF) and total slaughtered weight. 


\section{MATERIALS AND METHODS}

76

77

79

80

81

82

83

84

85

86

87

88

89

90

91

92

93

94

95

96

97

98

99

100

\section{Approval of the animal experiment}

The experiment was approved by The Danish Veterinary and Food Administration, the Ministry of Environment and Food (case no. 2015-29-21-00714).

\section{Probiotic strains}

Strains listed in Table 1 were provided freeze-dried in a powder formulation. Immediately before spraying, the strains were solubilized in deionized water. Whole genome sequencing (WGS) was used to characterize the strains genetically and to design strain specific PCR primers for identification [22].

\section{Distribution of probiotics directly in the hatcher}

The hatchers were of model Petersime (Zulte, Belgium) [25]. The spray devise to deliver the probiotic spray was designed as an independent unit that was placed in the hatcher at the same time that it was loaded with fertile eggs [26]. A dose of probiotics was approximately $5 \times 10^{8}$ cell forming units $(\mathbf{C F U})$ for each chick and was delivered in $1.0 \mathrm{ml}$ deionized water. After spraying, a sample of the probiotic solution was collected for counting of CFU (Table 1).

\section{Farm}

The NPC was tested in a conventional Danish broiler production farm.

Experiments 1 and 2 were carried out on the same farm in two similar buildings with respect to size, feed, watering system, ventilation and temperature controls. In the first experiment 15,400 Ross 308 chicks were inserted in both the probiotic treated and the control group. In the second experiment 15,000 chicks were included each group (Table 2). In experiment 1, the probiotic treated chicks were inserted in house 1 , and the control chicks in house 2 . In the second experiment, chicks treated with probiotics were inserted in house 2 and house 1 left for the 
101

102

103

104

105

106

107

108

109

110

111

112

113

114

115

116

117

118

119

120

121

122

123

124

125

126

127

128

129

control flock. The farm performed a thinning after 34 days where 5,000 and 4,500 broilers were removed for slaughter from each house, respectively from the two experiments followed by a final delivery to slaughter at day 38. The effect of the probiotics was measured by FCR [27], FWM and PEF [27], as well as total and average weight of birds at slaughter.

At day 14, 25 birds from the treatment and control flocks were euthanized by cervical dislocation and contents of ileum $(n=25)$ and cecum $(n=25)$ were collected and tested for the presense of the probiotic strains by culturing and PCR. Dead chickens were collected throughout the production period and immediately stored at $-20^{\circ} \mathrm{C}$.

\section{Probiotic strain recovery and identification}

The content of the ileum from the 25 euthanized birds (approximately $1 \mathrm{~g}$ wet weight per bird) were frozen in glycerol $\left(15 \% \mathrm{vol} / \mathrm{vol}\right.$ final conc.) and stored at $-80^{\circ} \mathrm{C}$ until further analysis. Samples were plated on Man de Rogosa, Sharpe broth [29] for recovery of lactobacilli and blood agar plates (BA) (5\% calf blood in blood agar base [30] for recovery of Enterococcus faecalis and E. coli and incubated overnight at $37^{\circ} \mathrm{C}$. From all BA and MRS agar plates, five presumptive E. coli, E. faecalis and L. agilis colonies were isolated per plate and pooled before suspension in in $100 \mu \mathrm{L}$ sterile filtered ultraclean water [31] for preparation of DNA templates. The samples were boiled for $10 \mathrm{~min}$ and centrifuged at $14,000 \times \mathrm{g}$ for 5 minutes. The supernatant was used as DNA template for PCR. PCR identification of the probiotic samples was made, using strain-specific primers (Table 2). To confirm the presence of the probiotic $E$. faecalis and L. agilis strain, boiling lysates were prepared in $85 \mu \mathrm{L}$ sterile filtered ultraclean water with $5 \mu \mathrm{l}$ lysozyme $(10 \mu \mathrm{g} / \mathrm{ml})$ and $10 \mu \mathrm{l}$ lysis buffer ( $200 \mathrm{mM}$ Tris $\mathrm{HCl}, 500 \mathrm{mM} \mathrm{KCl}, \mathrm{pH}$ 8.4) at $37^{\circ} \mathrm{C}$ for $20 \mathrm{~min}$. Hereafter, $4 \mu \mathrm{l}$ protein kinase $\mathrm{K}$ was added and digested for $60 \mathrm{~min}$ at $56^{\circ} \mathrm{C}$. The samples were centrifuged at $15,000 \times \mathrm{g}$ for $5 \mathrm{~min}$ at $5{ }^{\circ} \mathrm{C}$, the supernatant was transferred to a new tube and used for DNA PCR template. For samples found positive by PCR, single colonies from the primary plates were confirmed positive by the strain-specific PCR tests. Five single colonies were used to prepare DNA template from each sample.

\section{Post mortem examination of dead chickens}


The birds collected underwent a full post mortem examination including bacteriological sampling upon indication when vascular disturbances, exudations or enlargement of the liver was present. The yolk sac and/or liver were sampled with a sterile cotton swab after sterilising the tissue with a hot burning iron

\section{Bacteriology of E. coli and E. faecalis isolates collected during post mortem examination}

Bacteriological samples collected during post mortem examinations were plated on BA and grown aerobically overnight at $37^{\circ} \mathrm{C}$. From plates showing abundant and pure growth of presumptive $E$. coli colonies (circular with entire margins, low convex, medium size, nontransparent with a light greyish colour on BA) or E. faecalis colonies (smooth, circular colonies with entire margins, low covex and small size with a white to greyish colour), one single colony per sample was sub-cultured in Brain Heart Infusion Broth (BHI) [32] and stored in 15\% glycerol at $-80^{\circ} \mathrm{C}$. All isolates were tested with the strain-specific PCRs to verify whether the isolates were the E. coli and E. faecalis used as probiotics. In addition, all isolates which tested positive in the strain-specific PCR were typed by Pulsed-Field-Gel-Electrophoresis (PFGE) for comparison to the probiotic E. coli and E. faecalis (Table 1). The PFGE protocol for E. coli was used in a modified version [33]. The restriction enzyme Xbal was used [34]. The PFGE protocol for E. faecalis was described by Jørgensen et al. [35].

\section{Statistical methods}

Fischer's exact test was used for the analysis of data from GraphPad Prism5 [36] with a level of significance of $95 \%$. 


\section{Delivery of spray in the hatcher}

154

155

156

157

158

159

160

161

162

163

164

165

166

167

168

169

170

171

172

173

174

175

176

177

178

179

The spray device and delivery of the spray was initially tested without eggs in a hatcher with paper in the trays. Deionized water with Aviblue [37] as trace dye was used. Over $50 \%$ of the trays received the dye after a full spray event. Aerosols will also be taken up by the chicks and a higher proportion than $50 \%$ of chickens will probably receive the probiotics with a full hatcher.

The hatchability was not affected by the NPC treatment. The humidity increased from 29.3 to $30.8 \%$ during the $7 \mathrm{~s}$ activation of the spray device, however, the spray device did not affect the automatic humidity control in the hatcher.

\section{Survival of probiotic bacteria in the hatcher}

During the $24 \mathrm{~h}$ that the probiotic cultures were left in the hatcher at $37^{\circ} \mathrm{C}$, the CFU decreased with approximately one order of magnitude (Table 1).

\section{FWM and post mortem examiniation}

In experiment 1 , the FWM was 0.42 and $0.35 \%$ in the treated and the control house, respectively. With FWM below $0.7 \%$, the two flocks can be regarded as normal performing in regard of FWM [8]. In the second experiment FWM was 1.45 and $1.12 \%$ in the control and treated house, respectively. For this experiment the FWM may be regarded as higher than expected according to the broiler management manual [8]. However, the broiler breeders of the flock in experiment 2 were 54 weeks compared to 37 weeks in the first experiment which could explain the higher mortality. A total of 233 chickens dead on their own were collected for post mortem and bacteriological analysis. The most prominent lesions for chicken that died during the first week were yolk sac infections, sepsis, peritonitis, pericarditis and perihepatitis. For the first experiment, only 26 and $16 \%$ of the chickens collected as dead on their own during the first week from the probiotics and control flock, respectively allowed the isolation of $E$. coli in pure growth which could indicate an effect of the probiotic treatment, however, for the second 
experiment the similar figures were 73 and $95 \%$ for the probiotics and control flock, respectively [38] indicating that the probiotics did not affect the proportion of chickens which died due to $E$. coli during the first week.

The strains isolated during post mortem analysis were investigated with the strain specific PCR methods developed for the probiotic strains and were furthermore investigated by PFGE. In Experiment 1, none of the E. coli isolated from diseased chickens of the control group were identified as the probiotic E. coli strain by the strain-specific PCR. However, four of the $E$. coli isolated from the probiotic treated flock were positive for the strain-specific PCR of strain 730-281114-10n and showed identical PFGE banding patterns to the strain delivered in the inoculum. Three isolates were obtained from yolk sac infections and the fourth from sepsis. Furthermore, the two E. faecalis strains isolated tested positive in the strain-specific PCR for probiotic E. faecalis strain 336 and showed identical banding patterns by PFGE analysis compared to the probiotic strain. The two isolates were obtained from yolk sac infection and sepsis, respectively. The probiotic E. coli strain 730-281114-10n and E. faecalis strain 336 were excluded from experiment 2 based on the negative results.

\section{Re-isolation of probiotic bacteria from 14 day old chicks}

In experiment 1, the probiotic E. faecalis strain 336 and E. coli strain 730-28111410n were identified by PCR in 4 and $8 \%$ of collected ileum samples, respectively. The probiotic L. agilis strain 268 a was identified by PCR in 20 and $60 \%$ of the collected cecum and ileum samples, respectively.

In experiment 2, the probiotic E. coli strain L12 was identified by PCR in $8 \%$ of the collected samples, while L. agilis strain 268a was identified by PCR in 10 and $35 \%$ of the collected cecum and ileum samples, respectively. Two isolates of L. agilis from ileum were subsequently analysed by WGS and SNP analysis to confirm the identity to strain 268a of $L$. agilis. The two sequenceses only differed from the 268a genome by a single SNP and the isolates were concluded to be identical to the original strain.

In previous studies performed in experimental animal facilities it was demonstrated that the probiotic bacteria used in these two field experiments could be re-isolated from the 
209

210

211

212

213

214

215

216

217

218

219

220

221

222

223

224

225

226

227

228

229

230

231

232

233

234

235

236

237

238

majority of the treated chickens (data not shown). The intestinal flora will probably not change dramatically with time and the probiotic strains may be transient bacteria colonizing the chickens for the first weeks. In the current study the probiotic strain added with NPC were present during the first period of the production period where the chickens show the highest susceptibility to infections by pathogenic bacteria. The commercial strain SP1 was not tested for survival in the current study but has, previously been shown to survive for 30 days at $4^{\circ} \mathrm{C}$ in emmer beverage [39].

\section{Total weight and condemnation at slaughter}

The total mortality included dead animals in production, animals that died during transport and condemned animals. The total mortality was significantly higher in the probiotic flocks compared to the control flocks in both experiments (Table 3). The higher mortality in the probiotic treated flocks was balanced out by an increased in mean weight in the probiotic flocks. The mean weight of chickens accepted for consumption was 3.3 and $3.7 \%$ higher in the probiotic flocks compared to the control in experiment 1 and 2, respectively. The final slaughtered weigth accepted for consumption was higher in the probiotic groups compared to the control flocks in both experiments by 1.7 and $2.1 \%$ for experiment 1 and 2 , respectively (Table 3 ).

The number of condemned animals was higher in the probiotic treated flock $(1.66 \%)$ compared to the control flock $(1.49 \%)$ in the first experiment, while the number of condemned animals was higher in the control flock (1.02\%) compared to the probiotic flock $(0.93 \%)$ in the second experiment, neither were significant (Table 4$)$.

The number of condemned animals was significantly higher in the first experiment compared to the second in both the probiotic houses and the control houses $(\mathrm{p}<0.001)$. The proportion of condemned animals in the two houses were comparable to the three additional houses of the farm (data not shown) and to the normal in Danish production [40]. The higher condemnation in the first experiment compared to the second was mainly due to a significantly higher number chickens condemned due to irregular color/smell/consistency $(\mathrm{p}<0.001)$ (Table 4). This type of condemnation could not be directly related to infectious disease and was therefore not considered to have any association with the NPC treatment. Condemnations related to ascites were higher for the probiotics treatments compared to controls for both experiments, 
239

240

241

242

243

244

245

246

247

248

249

250

251

252

253

254

255

256

257

258

259

260

261

262

263

264

265

266

however, this condition predominaly has been associated with non-infectious causes. The number of animals condemned due to skin discoloration was not consistently related to the treatment with probiotics.

\section{FCR and PEF}

The PEF [28] index includes body weight, mortality and FCR [28] and can be used to evaluate the efficacy of the broiler productionon where a high value indicates an effective production. At the day of slaughter in the first experiment, the PEFs were 351 and 365 for the control flock and probiotic treated flock, respectively (Table 5). In the second experiment the PEFs were 379 and 375 for the control and probiotic treated flocks, respectively. However, PEF values include weight, mortality and FCR of the animals sent to the slaughter facilities. When calculating the adjusted FCR and adjusted PEF for the animals accepted for consumption, the FCR per accepted animal was poorer and the adjusted PEF was overall lower for all groups compared to the control. However, the adjusted PEF was higher in the probiotic flocks in both experiments (Table 5).

4

\section{CONCLUSIONS AND APPLICATIONS}

1. The test of the new probiotic concept under production conditions showed that the probiotic bacteria sprayed in the hatcher during the hatching process did not harm the chicks. However, in the first experiment, one probiotic strain of $E$. coli and one of $E$. faecalis was isolated from dead chicken in production and these strains were not included in the second experiment.

2. A higher total mortality was observed in the probiotic treatments compared to the control and the reasons need further examination. However, FWM including E. coli related infections or condemnations were not higher in the probiotics treated flocks compared to the control.

3. The mean weight of chickens and the total slaughtered weight accepted for consumption was higher in the probiotic flocks compared to the control in both experiments. 
4. The higher weight of animals in the probiotic treatment compared to the control was reflected in a higher PEF in the probiotic treated flocks compared to the control flocks but only when animals available for consumption were considered in the calculations.

5. Further investigations with the new probiotic concept are suggested to be done to test the persistence of the probiotics in the flocks and to test the concept under different management conditions.

1. Rodriguez-Siek, K. E., C. W. Giddings, C. Doetkott, T. J. Johnson, and L. K. Nolan. 2002.

Characterizing the APEC pathotype. Vet. Res. 33:239-250.

2. Nolan, L. K., H. J. Barnes, J.-P. Vaillancourt, T. Abdul-Aziz, and C. M. Louge. 2013. Colibacillosis. Pages 751-805 in Diseases of Poultry. D. E. Swayne, J. R. Glisson, L. R. McDougald, L. K. Nolan, D. L. Suarez, and V. Nair, ed. 13th ed. Wiley-Blackwell, Ames, Iowa.

3. Olsen, R. H., C. Frantzen, H. Christensen, and M. Bisgaard. 2012. An Investigation on firstweek mortality in layers. Avian Dis. 56:51-57.

\section{Christensen, H., and M. Bisgaard. 2016. Members of Streptococcus and Enterococcus} associated with disease in poultry. Pages 127-137 in A Laboratory Manual for the Isolation, Identification and Characterization of Avian Pathogens. S. M. Williams, L. Dufour-Zavala, M. W. Jackwood, M. D. Lee, B. Lupiani, W. M. Reed, E. Spackman and P. R. Woolcock, ed. $6^{\text {th }}$ ed. American Association of Avian Pathologists. Jacksonville, FL.

5. Poulsen, L. L., I. Thøfner, M . Bisgaard, J. P. Christensen, R. H. Olsen, and H. Christensen. 2017. Longitudinal study of transmission of Escherichia coli from broiler breeders to broilers. Vet. Microbiol. 207:13-18. 
295

296 6. Liljebjelke, K. A, C. L. Hofacre, T. Liu, D. G. White, S. Ayers, J. J. Maurer, and S. Young.

297

298

299

300

301

302

303

304

305

306

307

308

309

310

311

312

313

314

315

316

317

318

319

320
8. Anon. 2014. Ross 308. Performance objectives. Aviagen.

http://en.aviagen.com/assets/Tech_Center/Ross_Broiler/Ross-308-Broiler-PO-2014-EN.pdf

(accessed 16 December 2018)

9. FAO/WHO. 2001. Health and nutritional properties of probiotics in food including powder milk with live lactic acid bacteria. Report of a Joint FAO/WHO Expert Consultation on Evaluation of Health and Nutritional Properties of Probiotics in Food Including Powder Milk with Live Lactic Acid Bacteria. Córdoba, Argentina.

10. Kabir, S. M. L. 2009. The role of probiotics in the poultry industry. Int. J. Mol. Sci. 10:35313546.

11. Abdelrahman, W. H. A. 2014. Probiotics in Poultry Production - Concept and Applications. BIOMIN. 5m Publishing, Sheffield, UK.

12. Liong, M.-T. 2015 . Beneficial Microorganisms in Agriculture, Aquaculture and Other Areas. Springer. 
322 13. Frommer, A., P. J. Freidlin, R. R. Bock, G. Leitner, M. Chaffer, and E. D. Heller. 1994.

323 Experimental vaccination of young chickens with a live, non-pathogenic strain of Escherichia

324 coli. Avian Pathol. 23:425-433.

325

326 14. Peighambari, S. M., D. B. Hunter, P. E. Shewen, and C. L. Gyles. 2002. Safety,

327 immunogenicity, and efficacy of two Escherichia coli cya crp mutants as vaccines for broilers.

328 Avian Dis. 46:287-297.

329

330

331

332

333

334

335

336

337

338

339

340

341

342

343

344

345

346

15. Cao, G. T., X. F. Zeng, A. G. Chen, L. Zhou, L. Zhang, Y. P. Xiao, and C. M. Yang. 2013. Effects of a probiotic, Enterococcus faecium, on growth performance, intestinal morphology, immune response, and cecal microflora in broiler chickens challenged with Escherichia coli K88. Poult. Sci. 92:2949-2955.

16. Robyn, J., G. Rasschaert, D. Hermans, F. Pasmans, and M. Heyndrickx. 2013. In vivo broiler experiments to assess anti-Campylobacter jejuni activity of a live Enterococcus faecalis strain. Poult. Sci. 92:265-271.

17. Sadeyen, J. R., Z. Wu, H. Davies, P. M. Van Diemen, A. Milicic, R. M. La Ragione, P. Kaiser, M. P. Stevens, and F. Dziva. 2015. Immune responses associated with homologous protection conferred by commercial vaccines for control of avian pathogenic Escherichia coli in Turkeys. Vet. Res. 46:1-14.

18. Zhang, L., J. Li, T. T. Yun, W. T. Qi, X. X. Liang, Y. W. Wang, and A. K. Li. 2015. Effects of pre-encapsulated and pro-encapsulated Enterococcus faecalis on growth performance, blood characteristics, and cecal microflora in broiler chickens. Poult. Sci. 94:2821-2830. 
19. Z. Ševčíková, J. Blanár, A. Lauková, V. Revajová, V. Strompfová, and M. Levkut. 2016.

Effect of Enterococcus faecium EF 55 on morphometry and proliferative activity of intestinal mucosa in broilers infected with Salmonella Enteritidis. J. Vet. Res. 60:261-265.

20. Ribeiro, A., L. Vogt, C. Canal, M. Cardoso, R. Labres, A. Streck, and M. Bessa. 2007.

Effects of prebiotics and probiotics on the colonization and immune response of broiler chickens challenged with Salmonella Enteritidis. Rev. Bras. Ciência Avícola. 9:193-200. poultry feeds: A Review. J. Anim. Nutr. Physiol. 1:4-16.

22. DNA extraction was performed using the Maxwell@ FSC with the Maxwell@ DNA Purification Kit as recomended by the producer. DNA was sequenced by $2 \times 251$ bp paired-end sequencing on a MiSeq instrument (Illumina) and short reads were assembled using SPAdes v3.5.0 [23]. The Single Nucleotide Polymorphism (SNP) analysis was perfomed using the CSI Phylogeny 1.4 [24], by aligning and analyzing the sequence data of each genome against the probiotic L. agilis La3 reference genome (accession no.: NZ_CP016766). Lesin, S. I. Nikolenko, S. Pham, A. D. Prjibelski, A. V. Pyshkin, A. V. Sirotkin, N. Vyahhi, G.

368 Tesler, M. A. Alekseyev, and P. A. Pevzner. 2012. SPAdes: A new genome assembly algorithm and its applications to single-cell sequencing. J. Comput. Biol. 19:455-477. 
25. The inner size of the egg trays was $37 \mathrm{~cm}$ wide and $57 \mathrm{~cm}$ long and could hold 100 eggs. The sides of the trays were perforated vertically by $12 \mathrm{~mm}$ spacing leaving bars of $3 \mathrm{~mm}$ which allowed ventilation as well as the passage of spray with probiotics. The two sides of the hatcher each had room for $192 \mathrm{egg}$ trays (12 stacks of $16 \mathrm{~cm}$ in height) mounted on 3 wagons. For the experiments, only one side of the hatcher was treated with probiotics.

26. The spray device was based on a motorized knapsack sprayer (Maruyama, model 2 min. The unit was installed with a wireless switch (Keeloq, RF Solutions Ltd, Lewes, UK) and timer (TMR 48, Crouzet, Valence France) and it was powered by a rechargeable battery. Eight nozzles were mounted on the side wall of the hatcher and they were connected to the tank and pump by flexible tubing. The nozzles were of type Hcx 4 Gallon Blue (CBP2793, Micron Group, Bromyard). The device was activated by the wireless switch at $24 \mathrm{~h}$ before the hatcher was emptied. The device delivered $7 \mathrm{~s}$ pulses of spray with intervals of $7 \mathrm{~min}$. It took $8 \mathrm{~h}$ to empty the 131 of the tank. The movement of chicks and contact in boxes allowed further horizontal spread of probiotics between the chicks. The spray equipment including nozzles was cleaned with deionized water after application and externally disinfected with $70 \%$ ethanol.

27. The FCR was measured to describe the efficiency of the chicken to convert feed into body mass and was calculated as described by Aviagen in Ross Broiler Management Handbook [28].

395 The PEF is a performance measuring tool developed to give an overall performance value, 396 giving a standardized value for technical performance, including weight increase and mortality $397 \quad[28]$. 
402

403 29. MRS, CM0361, Oxoid, Basingstoke, UK.

404

405 30. Oxoid, Basingstoke, UK.

406

407 31. AnalaR Normapur, VWR chemicals, Leuwen, The Netherlands.

408

409 32. Difco, Brøndby, Denmark.

410

411

33. http://www.pulsenetinternational.org/protocols/(accessed 23 June December 2019)

412

413

34. Oxoid c/o Thermo Fisher Scientific ${ }^{\mathrm{TM}}$, Roskilde, Denmark.

414

415 35. Jørgensen, S. L., L. L. Poulsen, L. Thorndal, A. A. Ronaghinia, M. Bisgaard, and H.

416 Christensen. 2017. Characterization of Enterococcus faecalis isolated from the cloaca of "fancy

417 breeds" and confined chickens. J. Appl. Microbiol. 122:1149-1158.

418

419

36. https://www.graphpad.com/. (accessed 23 June December 2019)

420

421

37. Lohmann Animal Health, Cuxhaven.

422

423 38. $\mathrm{P}=0.337$ in experiment 1 and $\mathrm{P}=1.00$ in experiment 2 (Fischer's exact test). 
425 39. Coda, R., C. G. Rizzello, A. Trani, and M. Gobbetti. 2011. Manufacture and characterization

426 of functional emmer beverages fermented by selected lactic acid bacteria. Food

427 Microbiol. 28:526-36.

428

429 40. Claudi-Magnussen, C., and H. D. Larsen. 2011. Rapport: Automatiserede hjælpeværktøjer til 430 kødkontrol på kyllingeslagterierne. Udviklingsprojekt. Danish Meat Res. Inst. 1-31.

\section{Acknowledgements}

433 The NPC project was financed by GUDP (Grøn udviklings og

434 demonstrationsprogram), administrated by NaturErhvervsstyrelsen. The project was a

435 collaboration between Danhatch A/S, Sacco and University of Copenhagen. We thank Katrine

436 Aagaard for excellent technical assistance. 
Table 1. Probiotic strains and doses of cell forming units (CFU) used in the two experiments.

\begin{tabular}{llllll}
\hline & & & $\begin{array}{l}\text { Dry formulation of } \\
\text { probiotics per treatment }\end{array}$ & Predicted dose & $\begin{array}{l}\text { Measured dose in tank } \\
\text { when the hatcher was } \\
\text { emptied }\end{array}$ \\
\hline Species & Strain & Experiment & $\mathrm{g}$ & CFU/ml & CFU/ml \\
\hline E. coli & $730-281114-10 \mathrm{n}$ & 1 & 20 & $3.2 \times 10^{7}$ & $5.6 \times 10^{6}$ \\
E. coli & L12 & 2 & 20 & $1.3 \times 10^{6}$ & $\mathrm{ND}^{1}$ \\
$\begin{array}{l}\text { E. faecalis } \\
\text { L. agilis }\end{array}$ & 336 & 1 & 20 & $3.7 \times 10^{5}$ & $7.6 \times 10^{7}$ \\
& $268 \mathrm{a}$ & 1 & 20 & $2.9 \times 10^{8}$ & $2.2 \times 10^{7}$ \\
L. rhamnosus & SACCO SP1 & 1 & 20 & $2.9 \times 10^{8}$ & $2.2 \times 10^{7}$ \\
\end{tabular}

$\mathrm{ND}^{1}$, not detected 
Table 2. Genomic accession numbers of strains, PCR primers and PCR conditions used to detect probiotic strains.

\begin{tabular}{|c|c|c|c|c|c|c|}
\hline Species & Strain & $\begin{array}{l}\text { Accession } \\
\text { numbers of } \\
\text { genomic } \\
\text { sequences }\end{array}$ & $\begin{array}{l}\text { Primers } \\
5{ }^{\prime}-3{ }^{\prime}\end{array}$ & $\begin{array}{l}\text { Annealing } \\
\text { temp. } \\
{\left[\mathrm{C}^{\circ}\right]}\end{array}$ & $\begin{array}{l}\text { Product } \\
\text { size } \\
{\left[\mathrm{bp}^{1}\right]}\end{array}$ & $\begin{array}{l}\text { Prediction of match to } \\
\text { templale }\end{array}$ \\
\hline E. coli & $730-281114-10 n$ & PKGL01000000 & $\begin{array}{l}\text { F- GCATTTGCGTTAAGCAGTCA } \\
\text { R- ACAACGAAGCACTTCCCAAC }\end{array}$ & 58 & 140 & $\begin{array}{l}\text { Match target and } 26 \\
\text { other } E \text {. coli in } \mathrm{NCBI}^{2}\end{array}$ \\
\hline E. coli & L12 & PKGJ01000000 & $\begin{array}{l}\text { F- GGTCAGGGGAACAGCATAAC } \\
\text { R- GGATAAACCGGCTCATTTCA }\end{array}$ & 58 & 200 & $\begin{array}{l}\text { Match target and }>100 \\
\text { hits to other E. coli in } \\
\text { NCBI }\end{array}$ \\
\hline E. faecalis & 336 & PKGI01000000 & $\begin{array}{l}\text { F- AGAGCAAACGGCTCTCCTTA } \\
\text { R- TTTACGCTTTGGGTTTACGG }\end{array}$ & 58 & 957 & $\begin{array}{l}\text { Match only to target in } \\
\text { NCBI }\end{array}$ \\
\hline L. agilis & $268 \mathrm{a}$ & PKGH01000000 & $\begin{array}{l}\text { F- ATCCCAACTACGGGCTAACG } \\
\text { R- CCTCAAAATGGTCAAGAATTAGC }\end{array}$ & 58 & 322 & $\begin{array}{l}\text { Match target and } \\
\text { PKGM01000005, } \\
\text { PKGM01000047 of } \\
\text { L. agilis strain } 273 \text { in } \\
\text { NCBI }\end{array}$ \\
\hline
\end{tabular}

${ }^{2}$ NCBI, National Center for Biotechnology Information 
1 Table 3. Production parameters for experiment 1 and 2.

\begin{tabular}{|c|c|c|c|c|c|c|}
\hline \multirow[t]{2}{*}{ Animals } & \multicolumn{3}{|c|}{ Experiment 1} & \multicolumn{3}{|c|}{ Experiment 2} \\
\hline & $\begin{array}{l}\text { Probiotic } \\
\text { group }\end{array}$ & $\begin{array}{l}\text { Control } \\
\text { group }\end{array}$ & $\begin{array}{l}\text { Difference } \\
(\%)\end{array}$ & $\begin{array}{l}\text { Probiotic } \\
\text { group }\end{array}$ & $\begin{array}{l}\text { Control } \\
\text { group }\end{array}$ & $\begin{array}{l}\text { Difference } \\
(\%)\end{array}$ \\
\hline & \multicolumn{3}{|c|}{ Number of animals } & \multicolumn{3}{|c|}{ Number of animals } \\
\hline Inserted & 15,400 & 15,400 & 0 & 15,000 & 15,000 & 0 \\
\hline $\begin{array}{l}\text { Sent to } \\
\text { slaughter }\end{array}$ & 14,452 & 14,621 & 1.16 & 14,153 & 14,374 & 1.54 \\
\hline $\begin{array}{l}\text { Accepted } \\
\text { animals for } \\
\text { consumption }\end{array}$ & 14,147 & 14,361 & 1.49 & 14,002 & 14,218 & 1.52 \\
\hline Mortality & \multicolumn{2}{|c|}{$\begin{array}{l}\text { Dead animals } \\
(\% \text { mortality })\end{array}$} & $\begin{array}{l}\text { Significant } \\
\text { difference }\end{array}$ & \multicolumn{2}{|c|}{$\begin{array}{l}\text { Dead animals } \\
(\% \text { mortality })\end{array}$} & $\begin{array}{l}\text { Significant } \\
\text { difference }\end{array}$ \\
\hline In production & $\begin{array}{l}948 \\
(6.16)\end{array}$ & $\begin{array}{l}779 \\
(5.06)\end{array}$ & $\mathrm{p}<0.0001$ & $\begin{array}{l}847 \\
(5.65)\end{array}$ & $\begin{array}{l}626 \\
(4.17)\end{array}$ & $\mathrm{p}<0.0001$ \\
\hline Transportation & $\begin{array}{l}50 \\
(0.32)\end{array}$ & $\begin{array}{l}31 \\
(0.20)\end{array}$ & $\mathrm{p}<0.05$ & $\begin{array}{l}11 \\
(0.07)\end{array}$ & $\begin{array}{l}3 \\
(0.02)\end{array}$ & $\mathrm{p}<0.05$ \\
\hline Condemned & $\begin{array}{l}255 \\
(1.66)\end{array}$ & $\begin{array}{l}229 \\
(1.49)\end{array}$ & NS & $\begin{array}{l}140 \\
(0.93)\end{array}$ & $\begin{array}{l}153 \\
(1.02)\end{array}$ & NS \\
\hline Total & $\begin{array}{l}1,253 \\
(8.14) \\
\end{array}$ & $\begin{array}{l}1,039 \\
(6.75) \\
\end{array}$ & $\mathrm{p}<0.0001$ & $\begin{array}{l}998 \\
(6.65)\end{array}$ & $\begin{array}{l}782 \\
(5.21) \\
\end{array}$ & $\mathrm{p}<0.0001$ \\
\hline
\end{tabular}

\begin{tabular}{|c|c|c|c|c|}
\hline Total weight & Total biomass (kg) & $\begin{array}{l}\text { Difference } \\
(\%)\end{array}$ & Total biomass (kg) & $\begin{array}{l}\text { Difference } \\
(\%)\end{array}$ \\
\hline Total at & 36,705 & 1.91 & 36,047 & 2.04 \\
\hline
\end{tabular}

slaughter

facilities

$\begin{array}{lllllll}\text { Accepted for } & 36,169 & 35,556 & 1.72 & 35,847 & 35,095 & 2.14\end{array}$
consumption

\begin{tabular}{lcccccc}
\hline Mean weight & $\begin{array}{l}\text { Mean weight per } \\
\text { animal (kg) }\end{array}$ & $\begin{array}{l}\text { Difference } \\
(\%)\end{array}$ & $\begin{array}{l}\text { Mean weight per } \\
\text { animal }(\mathrm{kg})\end{array}$ & $\begin{array}{c}\text { Difference } \\
(\%)\end{array}$ \\
\hline $\begin{array}{l}\text { Total at } \\
\text { slaughter } \\
\text { facilities }\end{array}$ & 2.54 & 2.46 & 3.25 & 2.55 & 2.46 & 3.66 \\
$\begin{array}{l}\text { Accepted for } \\
\text { consumption }\end{array}$ & 2.56 & 2.48 & 3.26 & & & \\
\hline
\end{tabular}


Table 4. Percentage of animals in the different condemnation categories.

\begin{tabular}{|l|l|l|l|l|l|l|l|l|}
\hline Experiment & House & Treatment & $\begin{array}{l}\text { Skin } \\
\text { discoleration }\end{array}$ & $\begin{array}{l}\text { Irregular } \\
\text { color/odor/ } \\
\text { consistency }\end{array}$ & Ascites & Stunted growth & $\begin{array}{l}\text { Entrails } \\
\text { remaining }\end{array}$ & $\begin{array}{l}\text { Lack of } \\
\text { bleeding off }\end{array}$ \\
\hline 1 & 1 & Probiotics & 14.5 & 54.9 & 14.5 & 4.71 & 5.88 & 5.49 \\
\hline 1 & 2 & Control & 19.7 & 53.7 & 7.86 & 7.42 & 2.18 & 6.99 \\
\hline 2 & 2 & Probiotics & 20.7 & 29.3 & 21.4 & 6.43 & 17.9 & 4.29 \\
\hline 2 & 1 & Control & 14.4 & 35.9 & 15.7 & 1.31 & 26.1 & 6.54 \\
\hline
\end{tabular}


Table 5. Production efficiency for experiments 1 and 2.

Experiment 1

\section{Probiotic}

1.61

365

(PEF)

Feed Conversion Ratio (FCR)

Adjusted FCR for animals accepted for consumption

Adjusted PEF for animals accepted for consumption
1.70

1.73

1.66

1.64

355

343

372
Experiment 2

Probiotic Control

1.56

1.58

379

375

379

355

